\title{
Factors associated with tobacco and illicit drugs in students: contributions for nursing
}

\begin{abstract}
Objective: To identify factors associated with tobacco and illicit drugs in public school students.

Methods: This study is observational, cross-sectional, and analytical. The sample consists of 435 students from the fifth grade of elementary school to the end of high school. Data were collected through interviews using a structured questionnaire. For data analysis, the Poisson Regression Model was used. The discussion is anchored in Complex Thought in order to broaden the understanding of the phenomenon of tobacco and illicit drugs.
\end{abstract}

Results: Family income and the period of study were factors associated with the prevalence of risk, and dark-skinned people are associated with illicit drugs as an indicator of protection.

Conclusion: The health and social phenomena such as tobacco and illicit drugs should be perceived in a more expanded and contextualized way, in which the nurses have an inclusive and proactive role.

Keywords: selective transfer, superficial layer, structural analysis, intensity x-rays, width of diffraction lines, crystalline network constant
Volume 5 Issue 3 - 2018

\author{
Camila Biazus Dalcin,' Dirce Stein Backes, ${ }^{2}$ \\ Fabrício Batistin Zanatta, ${ }^{3}$ Jéssica Ineu \\ Dotto, ${ }^{4}$ Maria de Lurdes Lopes de Freitas \\ Lomba, ${ }^{5}$ Martha Helena Teixeira Souza ${ }^{2}$ \\ Universidade Federal de Santa Catarina, Brazil \\ ${ }^{2}$ Universidade Franciscana, Brazil \\ ${ }^{3}$ Universidade Federal de Santa Maria, Brazil \\ ${ }^{4}$ Universidade Federal do Rio Grande, Brazil \\ ${ }^{5}$ Escola Superior de Enfermagem de Coimbra, Portugal
}

Correspondence: Camila Biazus Dalcin, Universidade Federal de Santa Catarina, Brazil, Email camilabiazus@hotmail.com

Received: May 14, 2018 | Published: June 15, 2018

\section{Introduction}

The World Health Organization reveals that $33.33 \%$ of the population are smokers. ${ }^{1}$ It is estimated that 500 million people will die from tobacco use, regardless of quantity, quality and frequency of use. ${ }^{2}$ These data confirm the need to develop tobacco use prevention strategies, as well as investments in health promotion policies. Tobacco use affects $25 \%$ of the adult population, resulting in 5 million deaths per year. This value is much higher than the number of deaths associated with illicit drugs. ${ }^{2}$ The association between the use of illicit and tobacco drugs is revealed in significant demand, as teens who use tobacco are more likely to come to try drugs illegal. Most had invitation to tobacco use by school friends. ${ }^{3}$

The use of psychoactive substances has aroused international concern, with such issue considered a public health problem today, due to the increasing number of users ${ }^{4}$ Causes for the consumption of illegal substances are revealed in research with Mexican students, these being: impulsivity and aggression, have risk behavior of colleagues and be frequently exposed to violence, family conflict and at home drug use. ${ }^{5}$ In Brazil, the Oswaldo Cruz Foundation data show that 370,000 people are regular users of crack and/or similar forms of cocaine in the Brazilian capital. Of this total, about $14 \%$ are children and adolescents, representing a number of 50000 dependents. (6) Adolescence is the period in which the individual has the first contact with drugs. Therefore, this group has priority to scientific research focusing on changing attitudes and habits. ${ }^{7}$

Comparative study of health status, in the metropolitan region of São Paulo, showed an association between poorer health in vulnerable areas. In this context, it justifies the need to search for health indicators in areas that are in average condition, high and extreme vulnerability. ${ }^{8}$ However, there are weaknesses of the statistical data relating to tobacco, illicit drugs and the population of students in communities with less favorable socioeconomic data. Therefore, it recognizes the need for mapping in order to identify the reality of each area and population studied, with a view to possible intervention in the problems mentioned. ${ }^{5} \mathrm{New}$ thinking on social and health issues are pressing. It requires a paradigm shift in order to transcend the punctual and linear conception of social intervention and health model, in order to achieve strategies that address the human being in its multiple dimensions. It is an integrative thinking - Complex Thought -. Disjunctive elements that coordinates and promotes channels of communication from different perspectives and dimensions ${ }^{9}$

In this sense, the professional nurse occupies important place in the articulation of knowledge aimed at promoting healthy practices from a broader understanding of health. There is evidence ${ }^{10}$ that among the health professionals, the nurse stands by the integrator and perceptive look of the population's real needs and can meet the realities and transform them in a participatory and contextualized way. Considering the work of nurses in this integration process and transforming the social and health issuesrelated to health promotion, the study aimed to identify factors associated with tobacco and illicit drugs in public school pupils. After the analysis of these data, it was proposed discussion based on previous studies and in some Complexity Thought elements to achieve systemic understanding of the factors associated with the phenomena studied.

\section{Methods}

Observational cross sectional analytical, with the individual analysis unit. This research is part of the project "Promotion and health education of children and adolescents from public schools in a vulnerable community," funded by the Foundation for the Rio Grande do Sul Search - FAPERGS approved by Notice 02/2011 FAPERGS -PqG. The sample consisted of students between 10 and 19 years living in a community with approximately 26,000 inhabitants, in 
the western part of the municipality of Santa Maria, RS. This area was chosen based on economic indicators of vulnerability, social, environmental and health. ${ }^{11}$ Data were collected between October 2011 and December 2012. The sample size was previously estimated by sample calculation of the six schools public located in that community. This calculation was based on the formula: $\mathrm{X}$ nescola calculated $\mathrm{N}$ total $=\mathrm{N}$ total school/3659 (total in all schools). For the number of participants the same proportional systematic was carried out, considering the total number of students in each school and the total number departicipantes in each classroom. It was estimated sample 435 students from an endpoint of $50 \%$, a $95 \%$ confidence interval and a non-response rate of $30 \%$. Eligibility criteria included: students enrolled in public schools in age from 10 to 19 years and signing the Consent and Informed by the heads of school.

Data were collected through a questionnaire structured with the participation of researchers in the health field. The survey questions were based on previously testadoe questionnaire utilizadopela WHO applied to similar populations. ${ }^{12,13}$ Further, a pilot study was conducted with 15 students from schools surveyed. From the analysis of the results of this pilot study, some questions were modified to accurately survey. The data were presented by distribution of simple and relative frequency. The outcome variables were considered: "Do you smoke?" and "Have you ever used illegal drugs ever" ?. The independent variables were gender (male / female), age ( $\leq 14$ years $/>14$ years), race (white / other), living situation (parents / other), number of siblings $(\leq 2 />2$ ) family income ( $\leq$ U\$ $232.00 />$ U\$ 232.00), the education dichotomized by the median $(\leq 8$ years $/>8$ years $)$, school shift (day / night), failure in school (yes /no), occupation (only study / studies and works) and religion (has / has not).

Poisson regression models with robust variance adjusted and unadjusted were calculated to verify the relationship between the dependent and independent variables. In this model, the prevalence ratios (PR) and confidence intervals (95\% CI) were calculated. For multivariate analysis was performed an adjustment for all variables with $p<0.2$ in the univariate analysis. To select the variables that were retained in the multivariate model was adopted backward stepwise procedure, being eliminated one by one the variables with the highest value of $p$ to remain only the variables with $p<0.05$. Still, the variables "failure at school" and "race" have been retained in the final model for both outcomes, regardless of the value of $p$.

Thought complexity was chosen as a theoretical framework for the discussion of the results, in order to broaden and contextualize the understanding of the phenomena investigated. Issues such as illegal drugs and tobacco require seizure and complex discussion in order to articulate and interconnect the multiple dimensions and realities in which individuals are. For the theoretical discussion, in particular, was elected Organizational Tetragrammaton, which focuses on the dynamics of living systems from the order, disorder, interaction, and (re) organization from the perspective of Edgar Morin. ${ }^{14}$ The development of the study met the national and international standards of ethics in research involving human subjects.

\section{Results}

The results of the study showed no response rate of $10-13 \%$. Table 1 characterizes the population. It was found percentage of $5 \%$ of smokers and who have experienced at least one type of illicit drug, with $80 \%$ of students responded positively to both outcomes. Approximately $50 \%$ of the sample were female, had more than 14 years, more than 2 siblings, schooling greater than eight years of study and had failed at school. Approximately $36 \%$ were of other races, $22 \%$ had a family income below the minimum wage (US \$232.00) and had no religion.

Table 2 shows the prevalence of indicators associated with the outcome smoke. In the univariate model it was shown that individuals with lower family income or equal to $\$ 232.00$ showed a prevalence of smokers 4.7 times higher. With respect to shift the study and smoking, the night period was 2.9 times prevalence of students who make use of tobacco. As for the variable school failure, failure is prevalence indicator for being a smoker, increasing the likelihood of consumption 3.7. After adjusting variables: race, religion, family income, shift studies and school failure for the multivariate model, the variable school failure lost significance, remaining the statistical association between smoking and the variables family income and school shift . They appeared as indicators of prevalence, in the adjusted analysis to be smokers, family income (RP5, $4295 \%$ CI 2.39 to 12.28 ) and school shift (RP3, 72 95\% 1.64 to 8.43).

The analysis of the prevalence of indicators associated with history of illicit drug use was described in Table 3. In the univariate model, found that students of other races had a prevalence of the outcome $80 \%$ lower than the white race. As for family income, is less than or equal to $\$ 232.00$, rose 3.22 the prevalence of having been exposed to illegal drugs. Study at night increases the prevalence of 3.44 history of illicit drugs. The school failure was statistically associated with the outcome illicit drugs, and have flunked in school increased by 2.7 the probability of positive response. Was held, following the ajustedas independent variables in the multivariate model, in which were included race, number of siblings, family income, shift of study and school failure. The color was retained in the final model as protection indicator (RP0,20 95\% CI from 0.05 to 0.80 ) and prevalence as indicators for exposure to illicit drugs remained, family income (OR $3.6295 \%$ CI 1.58 8.30) and study shift (from 1.28 to 6.40 RP2,87 95\%).

Table I Characteristics of population studied

\begin{tabular}{lll}
\hline Characteristics & $\mathbf{n}$ & $\mathbf{( \% )}$ \\
\hline Sex & & \\
Female & 244 & $56,1 \%$ \\
Male & 191 & $43,9 \%$ \\
Age & & \\
$<14$ years & 220 & $50,6 \%$ \\
$>14$ years & 215 & $49,4 \%$ \\
Raga & & \\
White & 276 & $63,4 \%$ \\
Others & 159 & $36,6 \%$
\end{tabular}


Table continuded

\begin{tabular}{|c|c|c|}
\hline \multicolumn{3}{|l|}{ Housing situation } \\
\hline With parents & 370 & $85 \%$ \\
\hline With others & 65 & $15 \%$ \\
\hline \multicolumn{3}{|l|}{ Number of brothers } \\
\hline$<2$ & 236 & $54,2 \%$ \\
\hline$>2$ & 199 & $45,8 \%$ \\
\hline \multicolumn{3}{|l|}{ Religion } \\
\hline to possess & 335 & $77 \%$ \\
\hline Do not own & 100 & $23 \%$ \\
\hline \multicolumn{3}{|l|}{ Family income } \\
\hline$>\$ 232.00$ & 340 & $78,2 \%$ \\
\hline$<\$ 232.00$ & 95 & $21,8 \%$ \\
\hline \multicolumn{3}{|l|}{ Smoker } \\
\hline No & 415 & $95 \%$ \\
\hline Yes & 20 & $5 \%$ \\
\hline \multicolumn{3}{|l|}{ Illicit drugs } \\
\hline No & 415 & $95 \%$ \\
\hline Yes & 20 & $5 \%$ \\
\hline Occupation & 359 & $82,5 \%$ \\
\hline Study & 76 & $17,5 \%$ \\
\hline \multicolumn{3}{|l|}{ Study and work } \\
\hline Education & 229 & $52,6 \%$ \\
\hline$<8$ years & 206 & $47,4 \%$ \\
\hline \multicolumn{3}{|l|}{$>8$ years } \\
\hline Study shift & 340 & $78,2 \%$ \\
\hline Diumo & 95 & $21,8 \%$ \\
\hline \multicolumn{3}{|l|}{ Notumo } \\
\hline Disapproval at school & 233 & $53,6 \%$ \\
\hline No & 202 & $46,4 \%$ \\
\hline Yes & 435 & $100 \%$ \\
\hline
\end{tabular}

Table 2 Demographic and school prevalence indicators associated with smoking habit

\begin{tabular}{|c|c|c|c|c|c|c|c|}
\hline \multicolumn{8}{|c|}{ Use of tobacco } \\
\hline Sex & $\mathrm{n}$ & $\%$ & $\%$ of total & RP(IC95\%) & $\mathrm{P}$ & RP (IC 95\%)* & $P$ \\
\hline Female & 9 & 45 & 2,07 & 1 & 0,26 & & \\
\hline Male & II & 55 & 2,53 & I,62 (0,68-3,82) & & & \\
\hline \multicolumn{8}{|l|}{ Age } \\
\hline$<14$ years & 9 & 45 & 2,07 & I & & & \\
\hline$>14$ years & II & 55 & 2,53 & I,33 $(0,56-3,15)$ & 0,50 & & \\
\hline \multicolumn{8}{|l|}{ Raga } \\
\hline White & 17 & 85 & 3,91 & I & 0,06 & I & 0,060 \\
\hline Others & 3 & 15 & 0,69 & $0,31(0,09-1,06)$ & & $0,31(0,09-1,04)$ & \\
\hline \multicolumn{8}{|c|}{ Housing situation } \\
\hline With parents & 16 & 80 & 3,68 & I & 0,55 & & \\
\hline With others & 4 & 20 & 0,92 & $\mathrm{I}, 37(0,47-3,96)$ & & & \\
\hline \multicolumn{8}{|c|}{ Ninnero of sisters } \\
\hline$<2$ & 14 & 70 & 3,22 & I & 0,30 & & \\
\hline$>2$ & 6 & 30 & 1,38 & $0,6 I(0,24-I, 56)$ & & & \\
\hline \multicolumn{8}{|l|}{ Religion } \\
\hline to possess & 12 & 60 & 2,76 & I & 0,12 & & \\
\hline Do not own & 8 & 40 & $\mathrm{I}, 84$ & $2,0 \mathrm{I}(0,8 \mathrm{I}-4,94)$ & & & \\
\hline \multicolumn{8}{|l|}{ Family income } \\
\hline$>\$ 232.00$ & 8 & 40 & $\mathrm{I}, 84$ & I & 0,00 & I & 0,000 \\
\hline$<\$ 232.00$ & 12 & 60 & 2,76 & $4,7 \mid(I, 98-|I| 7)$, & & 5.19 & \\
\hline
\end{tabular}


Table continuded

\section{Occupation}

Study

Study and work

Education

$<8$ years

$>8$ years

Study shift

Diumo

Night

Disapproval at school

No

Yes

$14 \quad 70 \quad 3,22$
3,68

0,92

2,30

2,30

2,76

I,84

1,38
$I, 20(0,4 \mid-3,52)$

I

I,23 $(0,52-2,88)$

I

$2,90(1,23-6,83)$

I

$2,62(1,03-6,68)$

$(2,28-I I, 77)$

0,73

0,63

0,0

0,036

0,04

1

$2,06(0,80-5,32)$

*Street prevalence adjusted for pest, family income, tumor of studies and reprovacito in the selection-Variables that did not enter the adjusted analysis; Variables that were not retained in the final model.

Table 3 Demographic and school risk indicators associated with illicit drug outcome

\begin{tabular}{|c|c|c|c|c|c|c|c|}
\hline \multicolumn{8}{|l|}{ Illicit drugs } \\
\hline & & & $\%$ of total & RP(IC95\%) & $\mathrm{P}$ & $\mathrm{RP}(\mathrm{IC} 95 \%)^{*}$ & $\mathrm{P}$ \\
\hline \multicolumn{8}{|l|}{ Sex } \\
\hline Female & 10 & 50 & 2,30 & & 0,51 & & \\
\hline Male & 10 & 50 & 2,30 & I & & & \\
\hline Age & & & & I,32 $(0,56-3,10)$ & & & \\
\hline$<14$ years & II & 55 & 2,53 & & 0,75 & & \\
\hline$>14$ years & 9 & 45 & 2,07 & I & & & \\
\hline Raga & & & & $0,87(0,37-2,05)$ & & & \\
\hline White & 18 & 90 & 4,14 & & 0,03 & I & 0,023 \\
\hline Others & 2 & 10 & 0,46 & I & & $0,20(0,05-0,80)$ & \\
\hline Housing situation & & & & $0,20(0,04-0,87)$ & & & \\
\hline With parents & 16 & 80 & 3,68 & & 0,52 & & \\
\hline With others & 4 & 20 & 0,92 & I & & & \\
\hline Number of sisters & & & & I,4I $(0,49-4,06)$ & & & \\
\hline$<2$ & 15 & 75 & 3,45 & & 0,19 & & \\
\hline$>2$ & 5 & 25 & $\mathrm{I}, \mathrm{I5}$ & I & & & \\
\hline Religion & & & & $0,5 \mid(0, \mid 9-I, 40)$ & & & \\
\hline to possess & 14 & 70 & 3,22 & & 0,27 & & \\
\hline Nito Own & 6 & 30 & 1,38 & I & & & \\
\hline Family income & & & & $1,69(0,65-4,37)$ & & & \\
\hline$>\$ 232.00$ & 10 & 50 & 2,30 & & 0,006 & I & 0,002 \\
\hline$<\$ 232.00$ & 10 & 50 & 2,30 & I & & $3,62(1,58-8,30)$ & \\
\hline Occupational Therapy & 15 & & 3,45 & $3,22(1,38-7,50)$ & 0,75 & & \\
\hline Study & & 75 & & I & & & \\
\hline Study and work & 5 & 25 & $\mathrm{I}, \mathrm{I5}$ & I, $18(0,40-3,46)$ & & & \\
\hline Education & & & & & 0,62 & & \\
\hline$<8$ years & 10 & 50 & 2,30 & I & & & \\
\hline$>8$ years & 10 & 50 & 2,30 & I,24 (0,52-2,9I) & & & \\
\hline Turkish Studies & & & & & 0,004 & & \\
\hline
\end{tabular}

Citation: Dalcin CB, Backes2 DS, Zanatta FB, et al. Factors associated with tobacco and illicit drugs in students: contributions for nursing. Nurse Care Open Acces J. 20 I8;5(3): I52-I58. DOI: I0.I5406/ncoaj.20I8.05.00I39 
Table continuded

$\begin{array}{lllllll}\text { Daytime } & \text { II } & 55 & 2,53 & 1 & & 0,010 \\ \text { night time } & 9 & 45 & 2,07 & 3,44(1,48-7,99) & 0 & \text { I } \\ \text { Reprovactto at school } & & & & & 2,87(1,28-6,40) \\ \text { Nab } & 6 & 30 & 1,38 & 1 & 1 & 0,114 \\ \text { Yes } & 14 & 70 & 3,22 & 2,70(1,06-6,87) & 2,02(0,84-4,86)\end{array}$

\section{Discussion}

These limitations are related to the cross-sectional design. Factorsassociated with tobacco and illicit drugs in schools require statistical data analysis to enable comparative studies. The achievement of health planning for individuals, family and community is important to be reduced prevalence indicators such as family income and shift studiesThrough a multidimensional and complex look, transcending a linear view in different contexts. Thus, the nurse's performance in schools, families and communities constitutes a proactive strategy, the ability to understand the prevalence and associated enable (re) organization among schoolchildren exposed to family and social prevalence.

The prevalence of smoking in school has indices which vary with the population. A study conducted in Santa Catarina found that $4.7 \%$ of students report smoking. ${ }^{15}$ Fits here highlight limited availability of studies have shown results related to tobacco issues and illegal drugs in communities with vulnerability indicators. It is understood by those vulnerable communities who experience environmental, economic, political and cultural influences that weaken relationships, interactions and individual, family and social associations. ${ }^{16}$ another study ${ }^{17}$ conducted with adolescents observed prevalence of $6.3 \%$ of tobacco use in adolescents. Research (18) held in the Brazilian capital shows that there is no difference between the sexes for the use of tobacco. However, owning brown race decreased the prevalence of tobacco use, come to corroborate results from other races having a lower prevalence for the outcome smoke.

Tobacco use in adolescence is associated with the consumption of alcohol, to have separated parents, having smokers in the coexistence of young parents who rarely or never talk about drugs, the influence of the media and to be corrected by parents aggressively /coercitiva. ${ }^{17-19}$ smoking has decreased in the population above 18 years, which may be associated with the anti-smoking campaigns, however, it appears on the rise among adolescents. ${ }^{20}$ In school health education proves to be necessary to connect the teenager's actions, vulnerable at their time of life, and such a phase characterized by cognitive, biological, emotional and social changes. Exposure to behavioral risk factors such as tobacco and illicit drugs It is often in early adolescence. ${ }^{21}$

Drug addiction is multifactorial event and should be considered as a social event from all social strata and age groups, starting early in most reports. As the "V National Survey on Psychotropic Drug Use among Students of Elementary Education and Secondary Public School System in the 17 Brazilian Capitals" with a minimum age of 10 years, $22.6 \%$ of respondents reported having used some psychoactive substance. ${ }^{13}$ This study also showed a decrease in consumption, is related to other research, with the frequency of $5 \%$ in school. The prevalence rate of illicit drugs in the present study was different, was observed considering that a number of already consume $5 \%$, compared with previous $8.6 \%$ and $9.8 \% .^{17,18}$ and Age sex appearing in surveys prevalence indicators foruse of illicit drugs. Even though there have been no statistical associations between those variables in this study, there is a greater tendency for older teens men have tried an illicit drug.

Regarding gender, it was found that males (55\%) had a prevalence of slightly higher consumption compared to females (45\%) for smoking, and the exposure to illegal drugs this difference was not observed. These data are similar to those shown in studies conducted in Brazil, which showed higher consumption of any psychoactive substance among male students. ${ }^{23,24}$ The lower family income or equal to the minimum wage increased prevalence for both outcomes, with data on the prevalence of 5.42 and 3.62, for the tobacco and illicit drugsRespectively. These results differ from those calculated in another study ${ }^{22}$ in which an income above three minimum wages was prevalence indicator for the use of illegal drugs due to the purchasing power to acquire the drug. Through complex approach, multidimensionality enhances perception of determination, in which the school is vulnerable by the situation, but will not stay in that order. Regarding the school shift, study ${ }^{25}$ with 371 high school students from a public school in Goiás, it showed that there was prevalence of usedrugs at school studying in turn day compared to studying the night shift of $31.5 \%$, being the opposite in this study.

The school shift and family income are components of the system in which the individual It is inserted, and such related end up receiving the intervention of different outcomes that come to cause disorder in the organizationinitial. Biological issues seem to have less influence the outcomes of the socio-economic issues and behavior, leading to the need for (re) organization of the system through understanding of all individuals. Study of 831 adolescents in the eighth grade of Rondônia showed no significant associations between consumption, gender and race. ${ }^{26}$ School of breeds other than white's, had a prevalence of illicit drug use $80 \%$ less. Due to a Brazilian historical question of the south, this result may be associated with the prevalence of greater number of white individuals.

The systems in which students areinserted will appear as complex and multidimensional. For Morin, the orderIt is connected to the idea ofinteraction and can be thought of organizing process of individuals. ${ }^{14}$ Thus, the school has an order understood in organization and interaction with other individuals, family, community and other systems that comprise it. In this context, the order and disorder are complementary and competing simultaneously.

However it is the disorder that humans search strategies for a possible (re) organization..$^{14}$ When interveniências enter the adolescent system, such as family income and school shift, causing a disorder in the personnel system and other systems. From this perspective, it is considered important to know the school in its uniqueness and inserted in context, to understand the correlations with tobacco and illicit drugs. The interaction becomes the set of relationships, actions and retroactions that perform and are woven into a system. ${ }^{9}$ To strengthen ties with the school throughtrusts with health professionals, especially nurses, constitutes in proactive initiative and protective for achieving 
results in expanded health promotion in school..$^{19}$ The interaction must be worked at school and in the family, so that they constitute support networks front ofuncertainties of school, strengthening the links between the different actors that make up the health care system.

You can not reducethe organization of a system to order. Through a complex optical, you can deal with systems that are always on the verge of disorder, in which interveniências are seen as challenges that make it possible to (re) organization. ${ }^{9}$ Tobacco and illicit drugs are health and social phenomena involving multi-causal factors, ie complex. Family, community and school can mobilize the (re) organization of the school and also the social space of their new order. It is noticed that established family ties, dialogue and affection are possibilities for promoting healthy practices in personal and collective level. ${ }^{18,27}$

The fragmentation of systems is reducing, and the whole is only the emergence of interactive qualities. ${ }^{9}$ Therefore, to promote health in the perspective of complexity means grasp and understand each individual on your site and social context as well as understanding the interactions of all the organizational dynamics of each individual. In this process, the intermediationnurse, through expanded and systemic care, constitutes an important strategy to grasp and understand the individual / school in multiple dimensions, i.e. from systems that compose it.

\section{Conclusion}

Low family income and night school shift were the factors associated with tobacco and illicit drugs in public school pupils. The racewas associated only with the outcome of illicit drugs. Transcend the linear view of knowledge and health practices implies apprehending the phenomena tobacco and illicit drug extended and contextualized way.In this discussion space, the nurse appears as mediator and coordinator of healthy health care practices, especially with regard to the protection and promotion of health.

\section{Acknowledgments}

Thanks to the Coordination of Improvement of Higher Education Personnel (CAPES) for the master's scholarship and the Foundation for Research Support of the State of Rio Grande do Sul (FAPERGS) for the funding of the research.

\section{Conflicts of interest}

There are no conflicts of interest to report.

\section{References}

1. Nations Office for Drug Control and Crime Prevention. World Drug Report, 2009. Vienna: UNODC; 2009.

2. Castro M, Cunha S, Souza D. Violence behavior and factors associated among students of Central-West Brazil. Rev Saúde Pública. 2011;45(6):667-676.

3. Pratta M, Santos A. The Health-Illness Process and the Chemical Dependence: Interfaces and Evolution. Psicol Teoria e Psiqui. 2009; 25(2):203-211.

4. Negrete D, García-Aurrecoechea R. Psychosocial risk factors for illicit drug use in a sample of Mexican high school students. Rev Panam Salud Publica. 2008;24(4).223-232.

5. Fundação Oswaldo Cruz. Agência Brasil. Estimativa do número de usuários de crack e/ou similares nas Capitais do País. Livreto Domiciliar.
Rio de Janeiro: Fiocruz; 2013

6. Jinez M, Souza J, Pillon S. Drug use and risk factors among secondary students. Rev Latino Am Enfermagem. 2009; 17(2):246-252.

7. Barata R, Ribeiro M, Cassanti A. Social vulnerability and health status: a household survey in the central area of a Brazilian metropolis. Cad Saúde Pública. 2011;27(2).

8. Morin E. A cabeça bem-feita: repensar a reforma, reformar o pensamento. Rio de Janeiro: Bertrand Brasil; 2009.

9. Backes D, Erdmann A, Büscher A. Nursing care as an enterprising social practice: opportunities and possibilities. Acta Paul Enferm. 2010;23(3):341-347.

10. Marzari C, Backes D, Backes M, et al. The social-political-environmental and health reality of families belonging to a vulnerable community. Ciência \& Saúde Coletiva. 2013;18(1):77-84.

11. Galduróz J, Sanchez Zv, Opaleye ES, et al. Factors associated with heavy alcohol use among students in Brazilian capitals. Rev Saúde Pública. 2010;44(2):267-273.

12. Galduróz J, Noto AR, Fonseca AM. Levantamento Nacional sobre o Consumo de Drogas Psicotrópicas entre Estudantes do Ensino Fundamental e Médio da Rede Pública de Ensino nas 17 Capitais Brasileiras-2004. São Paulo: CEBRID-Centro Brasileiro de Informações sobre Drogas Psicotrópicas, Departamento de Psicobiologia, UNIFESPUniversidade Federal de São Paulo; 2005.

13. Morin E. Ciência com consciência. Rio de Janeiro: Bertrand Brasil; 2010.

14. Rosa M, João Filipe Feltrin Caciatori, Ana Paula Ronzani Panatto, et al. Tobacco use and associated factors among students of a university of Criciúma (SC). Cad saúde colet. 2014;22(1):25-31.

15. Grupo de Estudos e Pesquisa em Empreendedorismo Social da Enfermagem e Saúde (GEPESES). Validação de conceito de comunidade vulnerável na perspectiva da complexidade. Conceito discutido e validado no grupo de pesquisa. Santa Maria (RS): GEPESES; 2011.

16. Machado Neto A, Andrade TM, Napoli C, et al. Determinants of smoking experimentation and initiation among adolescent students in the city of Salvador, Brazil. J Bras Pneumol. 2010;36(6):674-682.

17. Malta D, Denise LP, Flavia Carvalho Malta Melo, et al. Family and the protection from use of tobacco, alcohol, and drugs in adolescents, National School Health Survey. Revista Brasileira de Epidemiologia. 2011;14(3):166-177.

18. Cordeiro E, Kupek E, Martini J. Smoking prevalence among students from Florianópolis, SC, Brazil and nursing contributions. Rev bras enferm. 2010; 63(5):706-711.

19. Farrelly M, Pechacek T, Thomas K, et al. The impact of tobacco control programs on adult smoking. Am J Public Health. 2008;98(2):304-309.

20. Malta D, Sardinha L, Mendes I, et al. Prevalence of risk health behavior among adolescents: results from the 2009 National Adolescent Schoolbased Health Survey (PeNSE). Cienc Saúde Col. 2009;15(2):3009-3019.

21. Araujo C, Castor E,Guimarães Nunes V, et al. Experimentation and regular use of illicit drugs by students in the city of Bragança, northeastern Pará. Revista Eletrônica Gestão \& Saúde. 2013;1972-1983.

22. Campos D, Lima H, Corradi-Webster C. Alcohol use in nocturnal high school students from amazonic context. Revista Espaço para a Saúde. 2011;13(1):15-22.

23. Neto C, Fraga S, Ramos E. Illicit substance use by Portuguese adolescents Revista Saúde Pública. 2012;46(5):808-815.

24. D'Orazio et al. Drug use and school performance among young teenagers and the school of a public school of Pires do Rio. Go Holos. 2013;29(5):305-314. 
25. Nader L, Aerts D, Alves G. Consumo de álcool, tabaco e drogas ilícitas em escolares adolescentes da rede pública de Porto Velho, XVIII Salão de Iniciação Científica e Tecnológica, 2010.
26. World Health Organization. Inequalites in young people's health. Health Behavior in School-Aged Children. International Report from 2005-2006. Health Police for Children and Adolescents. Geneva: WHO; 2008. 